\title{
Antihaemophilic factor deficiency, capillary defect of von Willebrand type, and idiopathic thrombocytopenia occurring in one family
}

\author{
E. K. BLACKBURN, J. M. MACFIE, J. H. MONAGHAN, AND \\ A. P. M. PAGE \\ From the Department of Haematology, The Royal Infirmary and Hospital, Sheffield, the City \\ and Children's Hospitals, Nottingham
}

SYNOPSIS Thrombocytopenia of the type found in idiopathic thrombocytopenic purpura is described $\mathbb{C}$ in a family with a deficiency of antihaemophilic factor, and a capillary abnormality. The propositus (father) has thrombocytopenia and abnormal platelet morphology, together with a plasma deficiency $\vec{z}$ of antihaemophilic factor, but normal capillaries. His two daughters each are deficient in anti- $-\stackrel{D}{-}$ haemophilic factor with normal platelets but abnormal capillaries.

In 1931, von Willebrand described a familial haemorrhagic disorder which he called hereditary pseudo-haemophilia. The bleeding diathesis, inherited as an autosomal Mendelian dominant, was associated with excessive haemorrhage following minor injury and with spontaneous bleeding from the skin and mucous surfaces. The prolonged bleeding time and increased capillary fragility were accompanied by a normal platelet count and morphology, and a normal blood coagulation time and clot retraction. Dogmatic views of its pathogenesis were not given at that time.

In recent years this disease has been more intensively studied. A number of workers have described cases associated with deficiency in antihaemophilic factor (Larrieu and Soulier, 1953; Alexander and Goldstein, 1953; Quick and Hussey, 1953; Soulier and Larrieu, 1954; Ingram, 1956; Schulman, Smith, Erlandson, Fort, and Lee, 1956; Nilsson, Blombäck, Jorpes, Blombäck, and Johansson, 1957; Nilsson, Blombäck, and Francken, 1958; Biggs and Macfarlane, 1958; Horler and Witts, 1958; Wilkinson, Nour-Eldin, and Israëls, 1958; Blackburn, 1961), while two of Blackburn's (1961) series had a deficiency of Christmas factor in addition to the basic capillary abnormality of von Willebrand's disease. Braunsteiner (1955) and Braunsteiner and

Received for publication 20 February 1961.
Pakesch (1956) showed that cases of von Willebrand's disease and those with abnormal plateleto function, as demonstrated by electron microscopical studies and thromboelastography, may occur in the same family. So far as we are aware, however, thrombocytopenia of idiopathic type has not been described before in families of this group. The two daughters in the present family have been included in Blackburn's (1961) series of 158 cases of primary capillary haemorrhage.

\section{LABORATORY METHODS}

The three affected members of the present family (father and two daughters) were investigated using the following methods.

For the bleeding time, an Ivy method, as described by? Biggs and Macfarlane (1957a), was used and the tourni quet test by the method of Bell, Lazarus, and Munros (1940).

Microscopy of nail-fold capillaries was carried out as described by Macfarlane (1941). The capillaries were examined for increased tortuosity, variation in calibres and defective contractility to trauma. The platelet coun was done by the method of Lempert (1935), and the whole blood clotting time by that of Lee and White (1913) The one-stage prothrombin test was one slightly modifiedo from that described by Biggs and Macfarlane (1957b) Prothrombin consumption was estimated by the methoof of Merskey (1950). The thromboplastin generation tes $\frac{5}{D}$ was carried out by the method of Biggs and Douglas 
(1953), and antihaemophilic factor titration by the method of Pitney (1956).

Standard methods were used for the determination of the haemoglobin level, red cell and total white cell counts and the differential white cell count.

\section{THE PATIENTS}

FATHER $\mathrm{He}$ is an auditor, aged 34 years, who, when referred to hospital, gave no history of taking cytotoxic drugs or of exposure to any toxic industrial hazard. There was a clear history of excessive bruising for about 14 years, and he had always bled abnormally after receiving cuts or abrasions. There had never been spontaneous haemorrhage from mucosal surfaces, but transient crops of small blue spots had been noticed under the armpits. Nettlerash had been observed from time to time on the shoulders. He had never had joint symptoms. At the age of 5 years he required blood transfusion after the removal of his tonsils and adenoids. He had been told that he bled for many days after this operation and that the bleeding stopped for one and a half days at one stage during this episode. After dental extractions he has always bled profusely for 12 hours and has continued to bleed for up to seven days in spite of local dental attention. One year previously he had been transfused with two bottles of plasma after dental extractions. His past illnesses included chickenpox, measles, mumps, tonsillitis, sandfly fever, and malaria.

He and his two daughters are the only members of the family who have been affected by abnormal bleeding. He has three brothers (one of whom has two sons), and one childless sister. His father, three paternal uncles and three paternal aunts and their children, his mother, one maternal uncle with no children and two maternal aunts, one of whom has two daughters and one son, are also unaffected by abnormal bleeding.

Laboratory findings The haemoglobin, red and white cell counts (including differential), red cell morphology, one-stage 'prothrombin' time, whole blood clotting time, bleeding time, tourniquet test, and capillary microscopy of the nail folds were all within the normal range. The platelet count was low (70,000 per c.mm.) and hypogranularity and many giant and small forms were seen. The prothrombin consumption index was high, $100 \%$ (normal well below $40 \%$ ). The thromboplastin generation test showed a plasma deficiency, and the titre of antihaemophilic factor was low, $30 \%$ (normal range 50 to $150 \%$ ). On previous occasions the platelet count had been as low as 20,000 per c.mm. and the bleeding time prolonged to 18 minutes. Bone marrow examination showed an increased number of abnormal megakaryocytes with maturation arrest.

DAUGHTER AGED EIGHT YEARS She has always bled excessively following cuts and abrasions, and has bruised with abnormal ease. Recurrent and troublesome epistaxes began at the age of 5 years. Small crops of purpura on the trunk and limbs have been noted from time to time. Dental extractions have always led to abnormal haemorrhage. On one occasion the removal of one tooth necessitated admission to hospital for one week, but transfusion was not necessary. The extraction of two teeth on another occasion resulted in admission to hospital for three weeks, and the need for blood transfusion. She has never had haemarthrosis.

Laboratory findings Haemoglobin, red cells, white cells, and platelets were normal. The bleeding time was 10 minutes (normal less than five and a half minutes), the tourniquet test negative, and the whole blood clotting time seven to nine minutes (normal). The thromboplastin generation test showed a deficiency in a plasma factor. The one-stage prothrombin time was normal. The prothrombin consumption index was $39 \%$ (probably abnormal). The antihaemophilic factor titre was low, namely $30 \%, 35 \%$. Capillary microscopy of nail folds showed that tortuosity and calibre variation was considerably increased with defective contractility to trauma of some forms.

DAUGHTER AGED FOUR YEARS She has always bruised abnormally easily and has bled excessively following cuts and abrasions. A plasma transfusion was necessary on one occasion when three teeth were extracted. Purpura and haemarthroses had not been noticed by her parents, but the former was present on examination in small crops over the shoulders as well as widespread bruising of the trunk and limbs.

Laboratory findings The haemoglobin, red cells, white cells, and platelets were normal. The bleeding time was nine and a half minutes (prolonged), the tourniquet test was positive, the whole blood clotting time 10 minutes (normal), the one-stage prothrombin time was normal, the prothrombin consumption index abnormal (50\%), and there was a deficiency in the patient's plasma fraction in the thromboplastin generation test. The antihaemophilic factor titre was low (25\%). Capillary microscopy of nail folds showed increased tortuosity and variation in calibre with defective contractility to trauma of some forms.

\section{DISCUSSION}

While a mild to moderate degree of thrombocytopenia is well known to occur in some haemorrhagic phases of von Willebrand's and allied diseases, it does not persist in between these episodes as it has done in the father of the two girls.

The precise significance of the vascular abnormality, thrombocytopenia, and plasma deficiency in antihaemophilic factor in this family is obscure at present. It would seem that most cases of von Willebrand's disease are inherited as an autosomal dominant (Biggs and Macfarlane, 1958; Pitney and Arnold, 1960; Blackburn, 1961) but this is not always the case (Blackburn, 1961). While the inheritance of the antihaemophilic factor deficiency in the father and two daughters in the present family follows such a pattern, the platelet and vascular abnormalities clearly do not do so. These three main 
abnormalities may show variable penetrance and expressivity as manifestations of a single affected gene. Alternatively they may be due to the expression of different genes which may be located on the same chromosome.

Recently Raccuglia and Neel (1960) described kindred of 311 individuals in whom Dutch ancestry predominated. The variable manifestations of haemorrhagic disorder included a prolonged bleeding time, a morphological defect in platelets, and antihaemophilic factor deficiency. Genetic analysis suggested that the bleeding tendency was determined by a single dominant gene of variable penetrance and expressivity. A 22-year-old Caucasian man was shown by Perry, Opfell, and Baker (1960) to have plasma deficiencies of antihaemophilic factor and of plasma thromboplastin antecedent factor in association with increased vascular fragility. Different members of his family, however, had isolated abnormalities of each of the three types mentioned and also variable combinations of all three defects.

We are indebted to Dr. Barbara Lawson for carrying out preliminary tests on the girls.

\section{REFERENCES}

Alexander, B., and Goldstein, R. (1953). J. clin. Invest., 32, 551.

Bell, G. H., Lazarus, S., and Munro, H. N. (1940). Lancet, 2, 155.

Biggs, R., and Douglas, A. A. (1953). J. clin. Path., 6, 23.

-, and Macfarlane, R. G. (1957a). Human Blood Coagulation and its Disorders, 2nd ed., p. 401. Blackwell, Oxford. (1957b). Ibid, p. 402.

- (1958). Brit. J. Haemat., 4, 1.

Blackburn, E. K. (1961). Ibid, 7, 239.

Braunsteiner, H. (1955). Wien. Z. inn. Med., 36, 421.

$\longrightarrow$, and Pakesch, F. (1956). Blood, 11, 965.

Horler, A. R., and Witts, L. J. (1958). Quart. J. Med., 27, 173.

Ingram, G. I. C. (1956). Brit. J. Haemat., 2, 180.

Larrieu, M. J., and Soulier, J. P. (1953). Rev. Hémat., 8, 361

Lee, R. I., and White, P. D. (1913). Amer. J. med. Sci., 145, 495.

Lempert, H. (1935). Lancet, 1, 151.

Macfarlane, R. G. (1941). Quart. J. Med., 10, 1.

Merskey, C. (1950). J. clin. Path., 3, 130.

Nilsson, I. M., Blombäck, M., and Francken, I. von (1958). Proc. 6th Congr. European Sosiety of Haematology, Copenhagen, 1957 Pt 2, p. 629. Karger, Basel.

-, , Jorpes, E., Blombäck, B., and Johansson, S-A. (1957). Acta med. scand., 159, 179.

Perry, S., Opfell, R., and Baker, M. (1960). Blood, 16, 1184.

Pitney, W. R. (1956). Brit. J. Haemat., 2, 250.

, and Arnold, B. J. (1960). Ibid, 6, 81 .

Quick, A. J., and Hussey, C. V. (1953). J. Lab. clin. Med., 42, 929.

Raccuglia, G., and Neel, J. V. (1960). Blood, 15, 807.

Schulman, I., Smith, C. H., Erlandson, M., Fort, E., and Lee, R. E. (1956). Pediatrics, 18, 347.

Soulier, J. P., and Larrieu, M. J. (1954). Rev. Hémat., 9, 77.

Wilkinson, J. F., Nour-Eldin, F., and Israëls, M. C. G. (1958). Lancet, $2,115$.

Willebrand, E. A. von (1931). Acta med. scand., 76, 521. 